Cathrine Holst and Anders Molander ${ }^{1}$

\title{
Epistemic democracy and the role of experts ${ }^{2}$
}

\author{
Accepted for publication in Contemporary Political Theory
}

\section{Abstract}

Epistemic democrats are rightly concerned with the quality of outcomes and judge democratic procedures in terms of their ability to 'track the truth'. However, their impetus to assess 'rule by experts' and 'rule by the people' as mutually exclusive has led to a meagre treatment of the role of expert knowledge in democracy. Expertise is often presented as a threat to democracy but is also crucial for enlightened political processes. Contemporary political philosophy has so far paid little attention to our reliance on experts and has not sufficiently addressed the question of how expertise can be used to improve the epistemic quality of democratic decision making. We believe this lack of interest is spurred by a too hasty acceptance of arguments dismissive of the political role of experts. The paper examines a series of often-cited epistemic objections and concludes that several of them are overstated or misconceived, yet they all reflect real difficulties that need to be addressed. On this background, we tentatively outline a set of mechanisms that can contribute to alleviating the irreducible problem of epistemic asymmetries and ensuring that experts really are experts and use their expertise in the right way.

Keywords: expertise; epistocracy; democracy; epistemic asymmetry; biases

\footnotetext{
${ }^{1}$ Alphabetical order. Authors have contributed equally.

${ }^{2}$ We thank two anonymous reviewers and Bo Rothstein, Raino Malnes, Jakob Elster and Jason Brennan for valuable comments as well as participants at the following workshops: Was Plato Right? Should the Experts Rule? (Nordic Political Association Conference, Gothenburg August 2014), Justification and feasibility: Unpacking the relationship between ideal and non-ideal theory (Centre Universitaire de Norvège à Paris, November 2017) and Expertise, Democracy and Non-Majoritarian Institutions (ARENA. Center for European Studies, University of Oslo, November 2017).
} 


\section{Introduction: democracy or epistocracy?}

The role of knowledge in collective decision making has been an important topic in political theory since Plato in The Republic recommended that states be run by philosopher kings. Recently, the topic has once more returned to the centre of the discipline in discussions of 'epistemic democracy' - that is, the idea that democracy can be defended not only in terms of fair procedures for decision making, but also in terms of the quality of outcomes (Anderson, 2006; Estlund, 1993, 2008; Goodin and List, 2001; Landemore, 2012; for overviews, see Peter, 2001; Schwartzberg, 2015). According to epistemic democrats, to justify democracy procedurally with reference to principles of citizens' freedom and equality is not enough. To be a desirable form of government, the rule of the many must have qualities that contribute to improving decisions (i.e. making outcomes better according to some procedure-independent criteria). Epistemic arguments for democracy combine the assumption that there are such criteria - some 'truth' about political matters - with the belief that they can be at least approximated by democratic procedures. These procedures are seen as 'truth tracking'.

In their argument for democracy's truth-tracking characteristics, epistemic democrats compare democratic rule with epistocracy, or rule of the knowers, and argue for the relative merits of democratic procedures, aggregative as well as deliberative (Estlund, 2008; Landemore, 2012). Although very valuable, this philosophical exercise tends to sidestep a basic fact of modern democracies, namely that political decision making is dependent on the use of expertise and must rely on expert knowledge to perform well. In contemporary democracies, there is a plethora of expert bodies, including supreme courts, independent central banks, a wide range of regulatory and audit agencies, and advisory committees. Commentators talk of the 'expertisation' of society and politics (Turner, 2003) and 'the rise of the unelected' (Vibert, 2007). Non-experts' reliance on experts raises a principal-agent problem, since non-experts are often not in a position to directly assess the epistemic quality of expert judgements. In this article, we take this expertise reliance and the epistemic 
asymmetry it involves as our starting point. We agree with epistemic democrats that a satisfactory normative account of democracy must refer to expected epistemic effects of democratic decision making, but we do not compare democracy and epistocracy as separate regimes. Rather, on the background of the cognitive division of labour in modern societies and the need to integrate experts into political processes, we are concerned about the role of expertise and processes of expertisation as a problem for democracies. To be sure, we are not short of contributions that express anxieties about the delegation of authority to experts. An influential treatment of expertise in democratic theory is Robert Dahl's discussion of 'guardianship' in Democracy and Its Critics (1989; see also Dahl, 1985). That expertise not only represents a threat to democracy but is also crucial for an enlightened democratic opinion and will formation, was underlined by John Dewey (1927) and, with reference to him, by the early Jürgen Habermas (1963/1974). Yet with some exceptions (e.g. Turner, 2003; Pettit, 2004; Christiano, 2012; Moore, 2017), contemporary political philosophy has not sufficiently taken 'the fact of expertise' (Holst and Molander 2017) into account and addressed the question of how expertise can be used to the advantage of the epistemic quality of democratic deliberation and decision making. It is our contention that this lack of interest is due to an all too easy acceptance of arguments critical or dismissive of the political role of experts, which are, although not without foundation, too often exaggerated or misframed. Accordingly, a key objective of this paper is to identify and explicate different arguments inherent in the diffuse scholarly discourse on the 'dangers' of expertisation and to review and reframe them to enable more specific and constructive discussions of expert arrangements' normative legitimacy.

In the following, we start out by locating the problem of expertise within an epistemic account of democracy (II). We go on (III and IV) to discuss a series of objections to the political role of expertise that in different ways involve epistemic considerations. There are, of course, 
arguments that stem from democratic considerations, ${ }^{3}$ but since we are concerned with the epistemic quality of decisions, we focus on arguments that put into question the reasons to trust expert judgements. On the background of these objections, several of which are misconceived or overstated, but all of which are to be taken seriously, we tentatively outline ( V) some mechanisms that can contribute to remedying the principal-agent problems raised by the use of experts. As political questions involve complex factual and normative assessments, a certain 'epistocratic drift' seems inevitable if political decision making is to be 'truth tracking' or sensitive to all relevant factual and normative considerations. Nonetheless, there are expert failures; experts may make unwarranted claims to authority and their authority may be misused. The challenge is therefore one of institutional design - that is, how to ensure that the experts which citizens, politicians and officials have to rely on are really experts and use their competences in the right way. 4

\section{Why not a democratically delegated epistocracy? ELLER: On the problem of expertise in epistemic accounts of democracy}

Epistemic arguments for democracy can be more or less demanding. A minimal argument is that 'democracy is at least as good as, and occasionally better than, a random decision procedure at making decisions, although it can be inferior to rule by the wise few or the lone genius' (Landemore, 2012, p. 8). The maximal version of the epistemic argument for democracy is the idea that 'democracy is at least as good as, and occasionally better than, any alternative decision rule' (Landemore, 2012, p. 8). According to Hélène Landemore (2012), who recently has given the most general account of this idea, democracy has, at least in theory, certain properties that make it epistemically superior to decision making by, for example, a

\footnotetext{
${ }^{3}$ A recent treatment is Jeffrey (2017)

${ }^{4}$ Compare the approaches in Buchanan (2004) and Elster (2013).
} 
group of knowers, even if we could identify in advance and agree on who the knowers are (Landemore, 2012, p. 3). She bases her argument on Hong and Page's Diversity Trumps Ability Theorem, which says that under certain conditions, cognitively diverse groups outperform less diverse groups of individually more capable persons as problem solvers (Page, 2007, ch. 6). Since larger groups are usually more diverse, Landemore generalises this diversity theorem into a Numbers Trump Ability Theorem. However, even if the first theorem should hold, ${ }^{5}$ it is not necessarily so that an epistemically optimal diversity is also the most inclusive. Why not include only those who contribute with either their ability or their diversity (Marti, 2013; Ancell, 2017)? And, given what we know about voters' ignorance and about how political preferences are formed based on identities (Brennan, 2013; Achen and Bartels, 2016), how can we assume that 'collective wisdom' will outperform expert judgements? Is not the Hong-Page theorem less an argument for inclusive democratic procedures than for large and diverse bodies of knowers (Brennan, 2016, p. 184)? These fundamental problems aside, Landemore does not adress the question of the proper role of expert arrangements within a democratic order. ${ }^{6}$ The relevant comparison for her is not between democracy and the 'technocratic branch of government' but between democracy and oligarchy when both are 'equipped with a competent army of experts'. Her conclusion is that "democracy should still, on average and in long terms, outperform oligarchy' (Landemore, 2012, p. 204). She considers the delegation of authority to expert bodies unproblematic as long as it is made in a democratic way (Landemore, 2012, p. 204). Yet this procedural answer sidesteps the question of how democracy and expertise can be linked to promote the alleged epistemic qualities of

\footnotetext{
${ }^{5}$ Brennan (2016: 181) has brought to our attention a critique of the mathematical foundations of the theorem by Abigail Thompson (2014).

${ }^{6}$ This point is also made by Moore (2017: 25) and (2014)
} 
democratic decision making and what tensions or trade-offs between democratic participation and expertise may be involved (Holst and Molander, 2017).

David Estlund's (2008) 'epistemic proceduralism' is of a less demanding kind. He does not assume that democratic rule will outperform an 'epistocracy of the educated' where the educated persons have more voting power than the others (2008: 207). On the contrary, it is not unlikely that 'removing the right issues from democratic control and turning them over to the right experts would lead to better political decisions, and more justice and prosperity' (Estlund, 2008, pp. 261-262). Nevertheless, he dismisses epistocracy on the grounds that political authority is not based on expertise but on a (qualified) general acceptability, and since there are reasonable disagreements concerning who the right experts are, a rule of knowers cannot meet the acceptability requirement. That we cannot know who the experts are is one of the classical objections against the expertisation of politics (see Dahl, 1989), which we will return to in the next section. For Estlund, an initial problem is that his argument sits uneasily with his public reason view on legitimacy (see Brennan, 2013): We often agree on principles without agreeing on how to interpret them more specifically, and if epistocracy can only be legitimate when there is no reasonable disagreement regarding the criteria of identifying experts, then how can democracy be legitimate given the many reasonable views on how general political principles should be interpreted and implemented? Moreover, Estlund, like Landemore, is, in the end, more concerned with explaining why we should prefer a democratic regime to an epistocratic one than with discussing what sort of epistocratic arrangements could be normatively acceptable under democratic conditions.

In this paper, our approach is that suggested by Thomas Christiano (2012, p. 29): How can 'a democratic society ... adequately utilize the intellectual resources a division of labour provides in a way that is compatible with the idea of rational discussion among citizens about policy and law'? Christiano describes expertise as a 'filter' in democratic processes with the 
potential of ensuring the 'truth sensitivity' of policies and legislation. How are we to design expert arrangements to make sure they function this way?

If we take it to be a minimal condition for expert arrangements to have normative legitimacy that their powers have been democratically delegated, we, in effect, allow for a lot of what contemporary democratic critics currently denounce and dismiss as 'post-' or undemocratic 'elitism', 'technocracy' and 'expert rule'. Is this our premise, what then woiuld be wrong really with delegating policy-making to experts without further inclusion of citizens and civil society, as long as doing so is licensed by elected parliaments, and as long as one could reasonably expect this to result in better, more efficient and even more equitable decisions, than decisions made by a democratic assembly or directly by the plebiscite? Under such conditions, there would seemingly be no democratic deficit (see even Christiano, 2012, p. 34). What we are left with is a prima facie case in favour of as much expert-guided and expertisebased decision making as possible, granted that there is an intimate relationship between filtering decisions through expertise (that is identifiable) and truth-sensitive decisions, and that democratic requirements are ensured in the sense of equal civil and political liberties, as well as democratic procedures of delegation.

Epistocracy by democratic delegation, as we may call it, will be disputed from the outset by those who regard epistemic output standards as alien to democratic politics. As Nadia Uribinati says: “...once episteme enters the domain of politics, the possibility that political equality gets questioned is in the air because the criterion of competence is intrinsically inegalitarian" (2014, p. 83). Demcocracy is, according to her, not "better than any other regime not because it produces good decisions but because it allows us to feel directly responsible for the decisions we make' (Urbinati, 2014, p. 104). However, it is possible to be sceptical to delegated epistocracy without subscribing to a non-epistemic conception of democracy: Other things may be wrong with delegated epistocracy apart from it being "intrinsically inegalitarian". From an epistemic perspective - and this is what 
interests us here -- the problem with delegated epistocracy is rather that it ascribes an cognitive authority to expertise and expert judgements that maybe unwarranted. More specifically, we think the following 10 claims would be central: (1) that we cannot know who the knowers or experts are when it comes to political issues; (2) that all political decisions have moral dimensions and that there is no moral expertise; (3) that expertise is only possible under conditions of 'normal science' and political 'well orderedness'; (4) that experts, like laypeople, make cognitive errors; (5) that experts, representing disciplinary perspectives or particular epistemic cultures, are one eyed, overstretch their competence and fail to see their own perspective as one of many relevant perspectives; (6) that experts may be influenced by self-interest or (7) have ideological commitments that bias their judgements; (8) that we cannot be sure that experts practise 'parrhesia' and speak truth to power; (9) that experts often lack the competence (or willingness) to translate expert knowledge to make it understandable for policy makers and concerned citizens; and (10) that experts do not understand the logic of politics and lack the ability of 'good' political judgement. Because of this, critics will argue that the legitimate space for epistocracy by delegation is non-existent or at least very limited. The worries raised in 1-3 are the more basic, since they also apply to ideal experts who do not commit to failures or are exposed to biases: We cannot know who the 'real' experts are, descriptive and prescriptive issues are inevitably intertwined in politics, and political and epistemological shifts can make experts and non-experts switch seats from one day to the next, irrespective of how well those we refer to as 'experts' perform. Thus, we will first examine these three worries ${ }^{7}$ II) and then return to the worries raised in $4-10$ in III.

Before we start our examinations, however, one flawed assumption that gives apparent strength to these criticisms should be addressed. It is sometimes argued that the fact that

\footnotetext{
${ }^{7}$ For an examination of 1 and 2, see also Holst and Molander (2017).
} 
distinguishing between $\mathrm{x}$ and $\mathrm{y}$ is difficult or impossible contributes to discrediting claims that include references to $\mathrm{x}$ or $\mathrm{y}$. For example, pertaining to 1 , since it can be hard to distinguish between experts and non-experts, we cannot distinguish at all and argue that some know more about a subject matter than others. Or, pertaining to 2 , since facts and values are intertwined, we cannot make use of arguments that refer to technical expertise as something distinguishable. Or, with regard to 6 , since it can be hard to distinguish between people's motivations, any argument assuming that experts or others operate on the basis of something distinguishable from private interests is naïve and suspect. Yet one cannot deduce from the lack of clear-cut criteria that there are no demarcating criteria at all or that all attempts to identify something as $x$ (and not $y$ ) are in vain. If 1-10 are to be upheld, this must be done on a different basis.

\section{Epistemic worries spurred by epistemic asymmetry}

(1) Undoubtedly, people often disagree about who the 'real' experts are. It is easy to say that decisions would improve if they were informed and even made by experts, but it is notoriously difficult to identify beyond controversy who are experts and who are non-experts in different cases. This is the basis of claim 1 above, formulated by Estlund and others: The fact that we cannot know for sure who the knowers are undermines claims of extensive powers for those who say they know.

Expertise is a comparative phenomenon. According to Alvin Goldman's (2001/2011, p. 114) definition, experts are those within a given domain who 'have more beliefs (or high degrees of belief) in true propositions and/or fewer beliefs in false propositions within that domain than most people do (or better: than the vast majority of people do)'. However, there must also be a threshold. In Goldman's (2011, p. 115) words, to qualify as an expert, 'a person must possess a substantial body of truths'. If someone knows marginally more about trivial aspects of something, then it does not seem right to call this person an expert. 
Moreover, experts possess not only accurate information, but also 'a capacity to deploy or exploit this fund of information to form beliefs in true answers to new questions that may be posed in the domain' (Goldman, 2011, p. 115). Real experts understand and internalise their knowledge in ways that make it possible for them to apply it to new intellectual and practical problems in their field.

When it comes to political decision making in contemporary democratic societies, different kinds of expertise are involved. There is a special relationship between expertise and science, since what counts as knowledge in modern societies must typically be validated according to scientific norms and procedures. But experts exist and can be identified in other capacities as well. Proper experts operate according to, or at least in ways that do not contradict with, scientific standards, but are not necessarily full members of scientific communities. There are, moreover, sources of expertise other than scientific training, such as especially relevant practical experiences: Experts can have come to know a lot about something by means of practical engagement with certain issues over time (Collins and Evans, 2007). Experienced civil servants can, for example, possess this kind of practically gained regulatory expertise in addition to their expertise acquired through scientific training and education; the same goes for civil society actors and interest group representatives that we often see enter into meaningful issue-specific discourse with scientific experts on the basis of practical field knowledge, typically combined with scientific training. Finally, an important distinction can be drawn between the ability to 'contribute' in a domain of expertise ('contributory expertise') and having enough competence in this domain to be able to make sense of what its contributory experts are saying and doing ('interactional expertise') (Collins and Evans, 2007, pp. 13-44). The latter is vital for the communication between different types of expertise and between experts and non-experts.

But non-experts, lacking in both contributory and interactional expertise, are not in an epistemic position to assess expert reasons. This asymmetry constitutes the basic and 
recurring problem with regard to the use of expertise in democratic decision making. Can the tension between democratic equality and the cognitive inequality between experts and non-experts somehow be resolved? Can there be a delegation of authority without political alienation, to put it as Robert Dahl did (1985, pp. 6-7)?

Traditionally, epistemology warns against relying on authority as a source of knowledge. In An Essay Concerning Human Understanding, John Locke famously listed reliance on authority (argumentum ad verecundiam) as one of the main sources of false beliefs (Locke [1690] 1997, Book IV, Ch. XVII, § 19, p. 605). Yet one is dependent on the testimonies of others, especially those of experts, and uses, in effect, 'arguments from authority' when appealing to expert opinion (Walton, 1997). This means that not only direct evidence but also trust are sources of knowledge (Hardwig, 1985, 1991). However, blind trust is irrational, and there must be some justification for believing in an expert judgement. But how can nonexperts ascertain the trustworthiness or reliability of experts? Hardwig suggests two strategies: one is to rely on other experts; the other is to rely on independent second opinions. Both of these strategies redistribute trust. The object of trust is no longer the single expert but his or her co-experts and, in the end, the epistemic or scientific community itself. The layperson/expert problem is thus rephrased in terms of what makes an epistemic community trustworthy.

Moreover, in a question at hand, there may be competing claims to expertise - what Goldman referred to as the 'novice/2-experts problem'. In addressing this issue, Goldman (2011, p. 116) listed possible evidential sources (incorporating Hardwig's two strategies): argumentative performance of experts, agreement from fellow experts in the field, experts' past track records, and evidence from interests and biases. The first source of believing an expert statement is 'dialectical superiority': If one of the experts scores best in an argumentative exchange, then this may be an indicator that justifies the inference that his or her conclusion is the more correct one. However, non-experts are variably able to assess 
experts' argumentative achievements. To be sure, sometimes it may be possible for most people to evaluate the consistency, accuracy and reasonableness of expert statements without extensive expertise in the field. In other cases, the problem is exactly that a real assessment of the quality of expert argumentation requires expert knowledge that non-experts lack.

Drawing a conclusion about expertise on the basis of agreement from fellow experts may be sound in some cases, but it is generally somewhat problematic. To what extent does the fact that more experts reach overlapping conclusions indicate that these conclusions are correct? History is full of examples of majorities of putative experts getting it wrong. According to Goldman, a central variable is experts' independence from one another: There are reasons for laypeople to emphasise the relative number of experts that approve of a statement or a theory if the experts in question have reached their conclusions independently of one another. But if experts support other experts without any independent investigation and assessment of the case in question, then expert consensus is of little value, and nonexperts may just as well rely on their own judgement. If so, we are once more confronted with the general layperson/expert problem.

This is also the case if laypeople are to choose among competing experts based on past track records, because to do so, they must be able to have justified beliefs about the cognitive quality of these experts' achievements. The same is very often the case when non-experts are to rank experts on the basis of possibly distorting influences from interests and biases. With regard to interests, these can be part of laypeople's assessments, but they cannot be decisive. An expert statement can be correct even if the expert in question has an interest in it being correct, and disinterested experts can possess little expertise or be real experts but be wrong in the case at hand. Moreover, evidence on pecuniary interests is more accessible for a novice than the subtler influence of biases. If all or most members of a community of experts have the same bias, then the problem of numbers becomes even trickier. Non-experts are then once 
more dependent on being able to trust epistemic communities' capability to sanction improper behaviour, reveal biases and correct themselves.

To summarise the discussion of claim 1 so far, there are criteria and procedures for nonexperts to identify experts. Real experts are accepted as experts by epistemic communities where members' expertise can have multiple sources (scientific training, practical experience, etc.) and can be more on the 'interactional' than on the 'contributory' side, or vice versa, but where all, as a rule, due to the special relationship between science and expertise, operate within the limits of what scientific standards allow for. The question is which communities qualify on this basis, including how they cope with and communicate scientific disagreements and uncertainty. Epistemic communities or members of such communities can make this or that promise but be more or less trustworthy. It is therefore in novices' interests to institutionalise mechanisms that contribute to assessments and the fostering of epistemic communities' credibility.

(2) Someone may accept that there are criteria and procedures for identifying scientific and technical expertise but reject the idea that there are experts when it comes to political questions. Political decisions involve questions about what is right and what is good, and since there are no moral experts, there can be no political expertise - or so the argument often goes. The first premise is obviously true. But to warrant the conclusion, the premise must be made stronger and claim that in all political decisions are facts inseparably intertwined with norms and values. We call this the strong version of the first premise (2a). The second premise (2b) says that even if one could know who the knowers are with regard to isquestions and refute 1 as far as scientific and technical expertise is concerned, it is impossible to identify experts and distinguish them from non-experts on issues involving normative matters. We are then back to a version of 1: One cannot know who the knowers are. But are the two premises tenable? 
An assessment of 2a must distinguish between the logical and empirical levels. On a logical level, it is not the case that is-questions and ought-questions cannot be distinguished. Descriptive and causal characteristics - questions of how things are, of why things are as they are, and of whether and how an intervention (e.g. the introduction of a new policy) has effects - are logically independent of questions of whether things ought to be like they are, how one ought to intervene and how one should assess the effects of an intervention. One can deduce neither what one ought to do from what is nor what is from how things ought to be. Hence, in principle, is- and ought-questions can be distinguished.

However, policymaking involves facts as well as norms and values, of course. For example, normative issues are involved in scientific-technical deliberations when it comes to conclusions about sufficient evidence, that is, when "enough" studies have been conducted to establish an effect. As Rudner showed in a classic article, non-epistemic values are included when the decision to accept a hypothesis requires that the seriousness of making a mistake be determined (see also Douglas 2009; Kitcher 2011). Yet, a radical thesis of the inseparability of is-questions and ought-questions seems hard to defend. In most policymaking we would, in the end, often come a long way with distinguishing factual from evaluative questions despite uncertainties and hard cases. Estimations of effects of policies, or within policy domains, are impossible without normative standards - effects must be assessed on or for something -- but once such standards have been settled, interpreted and operationalised, measuring effects seems like a relatively technical question for scientists. It is thus hard to see why one cannot talk of technical or scientific experts as a separate category. Hence, if there is no moral and ethical expertise - that is, $2 b$ - the implications of this must not be exaggerated, because there seem to be distinguishable technical/factual questions that can be made into proper objects for scientific investigations.

The default position in the literature on the question of moral expertise seems to be that there is no such thing. In democratic theory, this position has been put forward by 
Robert Dahl (1989). According to Dahl (1989, p. 66), there is no moral knowledge, and hence no moral expertise, because there are no methods for demonstrating the intersubjective validity of moral judgements. Nevertheless, he admitted that moral questions cannot be reduced to 'subjective' questions pertaining simply to different 'tastes'; there is scope for 'argument drawing on human reason and human experience' (Dahl, 1989, p. 67).

This raises the question of whether there cannot be moral experts after all. The answer to this question depends on whether one considers moral judgements to be justifiable (Gesang, 2010; see also Hoffman, 2012). If one subscribes to a strong non-cognitivist position, then there can be no moral expertise. However, all accounts that consider normative questions to be possible objects of rational discourse open up, in principle, to the existence of moral expertise. This is, in effect, what Dahl does: If some moral arguments are more qualified than others, then some may be better able to make qualified moral arguments than others.

On this premise, one could think of moral expertise in the following way (see also Gesang, 2010): "Someone familiar with moral concepts and with moral arguments, who has ample time to gather information and think about it, may reasonably be expected to reach a soundly based conclusion more often than someone who is unfamiliar with moral concepts and moral arguments and has little time" (Singer, 1972, p. 117). To talk about moral experts along these lines makes it possible to identify someone as more competent in answering moral questions. This does not imply that one regards non-experts as having inferior moral status. One can uphold the principle of 'equal concern and respect' while conceding that some are better informed and better at consistently pursuing moral arguments than others; for example, one can be better equipped to clarify what the principle of 'equal concern and respect' means with regard to a certain issue. In addition, moral experts in this sense do not necessarily act in morally superior ways. Moral expertise is the competence to state and clarify moral questions and to provide justified answers, and this competence can be 
developed by means of education and training. Finally, one can talk about moral expertise in more or less ambitious ways. On the one hand, there exist moral experts who conceptualise and elaborate on the meaning of involved norms, values and ends; who explicate the implications of pursuing this or that end or of defining this or that value in one way or another; who explore normative conflicts and the consequences of such conflicts; and so on. On the other hand, there exist moral experts who justify norms and political aims and argue for priorities and ways of balancing normative ideas and ideals. A 'justice expert' may defend this or that as the appropriate metrics of distributive justice and then suggest a principle of just distribution - for example, of healthcare - or state this or that as the reasonable way to approach a conflict between rights.

In addition to their special competence in normative analysis, moral experts must have competences that, to a certain extent, overlap with scientific expertise because they have to reason on the basis of relevant facts and take scientific theories in the actual domain into account (Hoffman, 2012).

Granted all this, we are not without criteria for identifying moral experts. This is not to deny that persons we have reason to recognise as moral experts - that is, as having a special competence in reasoning about moral matters - judge moral matters significantly differently, just as citizens do. This is what we have to expect due to what Rawls (1993, p. 54) called 'the burdens of judgment'. The reasoned disagreement between moral experts is therefore a resource for a democratic society and not something problematic: Their deliberations can contribute to public clarification about what is at stake in political issues and to more considered judgements among politicians and the public. One can recognise someone as a moral expert and learn from the expert's reasoning without agreeing with his or her judgements. The disagreement of experts is, of course, a major problem if one thinks of moral expertise as something one ought to defer to. Then there can be no moral experts in a pluralistic political community, since, as Daniel Viehoff (2016) argues, it is very likely that 
'the person I can reliably identify as being more reliable than I am is someone other than the person you can reliably identify as being more reliable then you are' (p. 419). In this situation, 'different persons have authority over each of us, and neither of them has general authority over our political community' (Viehoff, 2016, p. 419). As with the arguments of Estlund and Landemore, this argument is directed against the strong epistocratic claim 'that expertise justifies the subjects' duty to obey political decisions because they are made by experts' (Viehoff, 2016, p. 408). However, this is not our claim. What we are discussing are the anxieties about epistocratic arrangements within a democratic order, or epistocracy by democratic delegation. If one gives up the 'expert-obedience claim' and thinks of 'moral experts' in the way we have sketched, then persons can be identified and recognised as experts even if one's own considered judgement coincides only with some of the experts' judgements. Given 'reasonable pluralism' (Rawls, 1993, p. 36), this is what we have to expect. This does not mean that there is no problem of epistemic asymmetry. For example, how should citizens approach arguments based on highly complex theories of distributive justice? If they cannot assess them directly, then they have to use the strategies for indirect identification of expertise suggested by Goldman. Yet when using them, one is again dependent on trust in the epistemic communities to which the experts belong - be it, in this case, the community of moral and political philosophers or the more specialised epistemic communities connected to different policy areas. On what basis can one as a non-expert deem whether this or that community should be recognised as having the competences they claim to have?

(3) However, even if we would be able to know who the experts are, be they technical or moral - as far as there are ways to to identify relatively credible epistemic communities there is the additional worry that this only applies under 'normal' circumstances. We often see how fields or disciplines are characterized by rivalizing paradigms or research programs 
and how they, after periods of production of expert knowledge within the parameters of a certain cognitive framework, undergo epistemic shifts that changes the notions of what qualifies as expert knowledge. The sources of such shifts can be more or less internal to the epistemic community, spurred by theoretical or conceptual innovation, methodological breakthroughs or new technologies, but they can also be external and related to social and cultural changes, economic crisis or political ruptures. An example of is how the rise of new countercultures and social movements during the 1960s changed knowledge interests in the human and social sciences. Another more recent example is how the 2008 financial crisis has contributed to a renewed interest in Keynesian economics (see for example Akerlof \& Schiller 2009). The fact that there can be sharply competing epistemic cultures and implicative and sometimes radical shifts in expert standards and constellations makes the question of who the "real" experts are harder.

However, what this underlines, is the need for institutional mechanisms ensuring that novices can retain their trust in those who call themselves experts even during times of intensified epistemic and cultural contestation and political confrontations. To be sure, this kind of trust requires a basic level of political 'well orderedness' in the first place. Yet this applies to any proposal of institutional design and redesign that political philosophers (or others) may put forward, and is a problem and limiting condition not only for our approach.

\section{IV.Epistemic worries spurred by expert biases and mistakes}

Common to objections 4-10 is that they are about expert failures, while objections 1-3 are of an inherent epistemological nature and apply even under the ideal condition of flawless expertise. We have suggested so far that these worries are, in the end, addressable. However, the arguments about how and why experts continually fail remain: Maybe we should not object to expert arrangement for epistemological reasons but on the basis of evidence of how actual experts actually tend to behave. 
(4) That experts make errors is a well-known fact. Research in cognitive psychology has also shown that expert judgements are more exposed to elementary fallacies stemming from the use of the intuitive System 1 than we like to think, and that formulas (statistical models) may outperform case-based expert judgements (Mehl, 1954; Tversky and Kahneman, 1974; Tetlock, 2005; Kahneman, 2012). But it is reasonable to assume that experts, when they are using wellestablished scientific methods and follow the rules of scientific reasoning, are less prone to making errors than laypeople. The effects of scientific canons on experts can be compared to the sobering effect of foreign language on ordinary people. Most of us tend to make fewer errors when answering questions in a foreign language (Sunstein, 2014, p. 101). Similarly, experts are induced to switch to 'System 2'.

Yet experts have a dubious reputation as forecasters. In Expert Political Judgment, Philip Tetlock (2005) presents results from studies of experts' ability to make economic and political predictions. Experts turned out to be overconfident: Their answers to questions scored bad on accuracy, especially if they were 'hedgehogs' who 'know one big thing' in contrast to 'foxes' who know 'many things'. The average expert did about as well as those who do random guessing, or 'dart-throwing chimps'.

However, Tetlock asked difficult questions that even experts themselves regarded as 'hard' (see Caplan, 2007; Quirk 2010), and Tetlock himself has criticised the way his research has been used to debunk expertise (Tetlock and Gardner, 2016). In a recent project, he and his research partner Barbra Mellars invited more than 20,000 lay people to answer questions about global issues. Some of them turned out to be very good at making forecasts, and what characterised these 'superforecasters' was their systematic and open-minded approach to the tasks they were given and their ability to detect mistakes arising from rapid System 1 operations. When working in diverse teams, superforecasters performed even better (Tetlock and Gardner, 2015, ch. 9). These findings are relevant to understanding what constitutes real 
expertise and how to counteract overconfidence and improve expert performance. How are we to hold experts to account in ways that induce them to take on the intellectual outlook that was found among the superforecasters?

(5) There is an old saying that for one who possesses a hammer, everything is a nail. Experts are no doubt often too confident of their own competence (Angner, 2006); they identify with their disciplines and are prone to frame problems so that they fall within their disciplinary matrices, paradigms or 'epistemic cultures' (Buchanan, 2004; Lamont, 2009). For example, engineers, lawyers and economists tend to approach environmental policy differently, focusing on technology, regulation and taxes/dues, respectively (Tellman, 2012). There is, on the one hand, an obvious case for disciplinary diversity in expert bodies to counter tip-of-thenose perspectives. On the other hand, that experts are committed to their disciplines and epistemic communities can be seen as a mechanism ensuring that they act according to shared epistemic standards and norms (Tellman, 2016).

(6) Another objection is that experts may be more or less biased by their self-interests. A statement from the philosopher Robert Spaemann in a 2008 German parliament commission on the permissibility of using human embryonic stem cells in research can exemplify this: "I take the liberty of a final remark on the status of the 'experts' questioned. As an independent authority can only be considered whoever is not committed to a particular interest by his professional status. Thus, not researchers working with embryonic stem cells or representatives of research institutions under whose ceiling such research takes place. They are an interested party and must be viewed as competent lobbyists. Their ... advice must be relativized and deserves no more hearing than that of a reflective nurse' (cited in Zenker, 2011:362). In a well-functioning political system, manifest conflicting interests are normally taken care of by the procedures for the selection of experts. However, even if there are no direct ties to parties who are interested in a certain outcome, experts may favour outcomes 
that are to their own advantage - for example, those that confirm positions they have defended, be it in academic or more public settings, and so bolster their professional reputation, or those that resonate with strongly held personal values and beliefs. To be sure, when someone is publicly appointed to give expert input, this constitutes an act of entrustment, establishing a principal-agent relationship, and such relationships always involve agency risks. Yet what is called for in such cases are mechanisms that reduce these inherent risks, and in the expert case in particular, a criticist frame of discourse and the institutional prerequisites for such discourse.

(7) The same applies for the particular charge that experts have ideological commitments or other deeper normative orientations that influence their judgements. Once more, the problem goes beyond the easily detectable cases: when experts explicitly embed their decisions or advice in a particular ideological or political outlook. Numerous examiners of social science from Gunnar Myrdal (1930/1953) onward have noted how theoretical approaches may frame the problem at hand in such a way that some value options are tacitly favoured. For example, neoclassical economics frames problems in a way that favours market solutions. The adequate response to this challenge is probably not to dismiss the role of social science or other kinds of expertise altogether, but to call for a relevant theoretical pluralism in cases where one suspects theory choice to have normative implications.

(8) Yet another worry is that experts belong and identify with the societal or 'power elite', and that their elite position and frame of reference compromise their independence: Experts are supposed to 'speak truth to power' (Wildavsky, 1979), but their connections to the 'establishment' tend to make them more affirmative than critical of the powers that be. This suspicion is a common ingredient in populist politics but is also fuelled by sober sociological scholarship on elite recruitment, formation and networks. Furthermore, despite its crudeness, 
the populist suspicion points to the circumstance that the duty of truth telling (what the Greeks called parrhesia) requires courage because it may involve personal risks (Foucault, 2001). However, non-experts should avoid the vulnerable situation of becoming exclusively reliant on the presence of individual experts' heroic virtues. This calls for thinking in terms of institutional norms and prerequisites for trustworthiness of experts.

(9) The objection that experts lack the ability to translate resonates with common experiences. No doubt, experts are often bad at stating arguments in a comprehensible way: 'People have a hard time taking the perspective of a less knowledgeable individual, and the gap is only wider for experts addressing laymen' (Mercier, 2011, p. 321). Because of elitist or paternalist attitudes, experts may also be unwilling to communicate in ways that reach out more broadly to stakeholders and the affected. Such translation problems, be they due to experts' limited abilities or lack of adequate motivation, add to the already troublesome situation of epistemic asymmetry between experts and non-experts. Due to cognitive inequalities, it is hard for nonexperts to hold experts to account. If experts are also bad communicators, then the situation will only worsen. However, the solution is not to debunk expertise but to encourage and demand that expert communities cultivate interactional and dialectical skills and consistent epistemic motivations.

(10) The last objection is that experts lack an understanding of political processes and the ability to make political judgements, since they tend to view political questions as if they were questions of facts and logic. On the one hand, this may result in recommendations that are 'right', in the sense that they are supported by solid evidence but lack political feasibility, at least here and now. A variant of this is when experts give unfeasible recommendations because they ignore institutional political conditions for their implementation (Swift and White, 2008). On the other hand, experts may exaggerate the extent to which the space for political action is 
constrained by Sachzwang, by given circumstances and parameters. The result in the first case is some kind of utopian engineering; in the other, the result is an adaptive, technocratic engineering that considers revisable facts and questionable concerns as 'necessities'. There are historical and even disastrous experiences of both types of mentality, and what they teach us is the need for institutional mechanisms that make it less likely that such mentalities will come to flourish.

In other words, from these objections (4-10), it would be a mistake to draw the conclusion that laypeople are as likely to be right as are experts, or that relying on experts inevitably disturbs the logic of political discourse rather than enhances its quality due to the risks of expert biases and mistakes. What is called for are mechanisms that can prevent expert failures and secure against misuse of expertise. The central question is thus how institutions can be designed to better ensure that identified experts will perform their democratically entrusted tasks in an acceptable, and preferably in the best way, possible.

\section{Mechanisms to ensure trust in experts}

Following this guiding thread we may distinguish between three sets of institutional mechanisms with different targets. One group of mechanisms targets expert behaviour, a second group the judgements of expert and a third the conditions for for expert inquiry and judgement.

To the first category belong the dos and don'ts of scientific communities aimed at guaranteeing the pursuit of truth through a fair competition between arguments. The adherence to such epistemic norms, spelled out, for example, by Merton (1942/1973), Habermas (1972/1984) and Tranøy (1976), is presupposed when political authorities and citizens appeal to expert opinion. In the end, the latter have to rely on the functioning of scientific communities (i.e. that the norms of inquiry are enforced through mutual scrutiny and criticism). This is the predicament of epistemic asymmetry, but political authorities can 
influence on the conditions for their own trust. Decisions they take about the external organisation of science and research, about funding of research and distribution of funds between different branches of research and so on, may have effects on the internal functioning on scientific communities. The way of organising expert bodies and public commission may also be of importance for making the scientific ethos effective. In addition, more specific measures can also be taken. For example check of putative experts academic merits, past records, vested interests and political affiliations in order to exclude unsuitable persons from assignments.

The second group of mechanisms aim at holding experts accountable by putting their judgements under review in different fora (Reiss 2008: 38 ff). The primary forum for testing judgements and detecting fallacies and biases is the forum of peers. However, in a process of democratic decision making, the testing of judgements and arguments must be extended from this forum - and, if necessary, from experts in other relevant disciplines - to the legislature and other political bodies, and even to the public sphere at large. In these fora, experts can be asked to account for critical assumptions, explain models used, specify their limits and present alternative models (se Schlefer 2012: 280-281). Of special importance is to demand of them to account for their area of expertise - that is, that the tasks they are entrusted with lie within their domain of expertise. Mechanisms of this kind may influence to what extent experts are considered trustworthy, but they may also counteract expert failures, for example that they fall victim to overconfidence or are insensitive to the evaluative, non-scientific dimensions of a problem.

The third group of mechanisms targets the conditions for expert inquiry and judgement. Epistemic self-constraint is closely related to the existence of cognitive diversity and an adequate intellectual division of labour. But experts who reason alone are also exposed to the "confirmation bias", which is the tendency to only look for arguments that confirm their own ideas, and to "reason-based choice", which is the tendency to pick the 
option for which reasons can be most easily gathered. Deliberating groups are less prone to these fallacies, and they may also enlarge the pool of ideas and information and weed out bad arguments (Mercier, 2011). However, the positive epistemic effects of deliberation are dependent on diversity. Without diversity, deliberation may work in the opposite direction and create groupthink (Sunstein 2006, Sunstein and Hastie 2015). Hence, organising expert work along team and deliberative lines and providing for necessary diversity and exposure to criticism from the wider epistemic community are important ways of fostering epistemic modesty and improving the quality and conditions of expert inquiry and judgement. Crucially, cognitive diversity also involves cooperation between different disciplines and fields consciously brought in to explain a subject matter from different angles. This includes a cooperative division of labour between factual and normative analysis.

The extension of the obligation of experts to explain and justify their judgements to public fora consisting of non-experts is required not only from the point of view of democratic procedures, but also arguably from the perspective of cognitive diversity. However, the outcomes of exchanges between experts and non-experts are ambiguous for the latter. There is evidence that non-experts pay less attention to the quality of arguments put forward by experts than by non-experts, since they tend to believe that experts know what they are talking about. There is also a range of ways that debating in front of an audience can reduce the quality of the arguments used by experts and the quality of the outcome (see also Elster, 1995). Mere publicity may even be detrimental to the quality of expert deliberation (Meade and Stasavage, 2008). Once fora that include non-experts are mobilised, we are again confronted with the layperson/expert problem, since non-experts, be they parliamentarians, officials or ordinary citizens, only to a limited degree will have the competence that is needed to assess expert statements and justifications directly.

\section{Concluding remarks}


Sharing with epistemic democrats the concern for the quality of the outcome of democratic decision making, we take a certain epistocratic drift to be inevitable if political decision making involving complex factual and normative assessments is to be 'truth tracking' or sensitive to all relevant factual and normative considerations. There are fair things to say about the ten epistemic objections against giving experts a role in political decision making that we have reviewed, but they do not make up a decisive case against what we have called epistocracy by delegation. Given the fact of expertise, we have argued that the key issue is one of institutional design: to instutionalize and make efficient mechanisms that ensure putative experts' expertise and that their performance adhere to epistemic standards. The mechanisms that we have outlined tentatively is no panacea and it is a question for empirical research to investigate whether they will work the way we suggest, and if so, how. Yet, we believe thinking about democracy's expert reliance and contemporary expertisation along the lines we have drawn will give us a better understanding of where the challenges lie. In the end, epistemic asymmetry and the problem of epistemic trust cannot be eliminated, but remedial mechanisms can be put in place.

\section{References}

Achen, C.H. and Bartels, L.M. (2016) Democracy for Realists: Why Elections Do Not Produce Responsive Government. Princeton, NJ: Princeton University Press.

Akerlof, G.A. and Shiller, R.J. (2009) Animal Spirits. How Human Psychology Drives the Economy, and Why It Matters for Global Capitalism. Princeton, NJ: Princeton University Press.

Ancell, A. (2017) Democracy isn't that smart (but we can make it smarter): On Landemore's Democratic Reason. Episteme 14(2): 161-175.

Anderson, E. (2006) The epistemology of democracy. Episteme 3(1-2): 8-22.

Angner, E. (2006) Economists as experts: Overconfidence in theory and practice. Journal of Economic Methodology 13(1): 1-24. 
Brennan, J. (2013) Epistocracy and public reason. In: A. Cudd and S. Scholz (eds.)

Philosophical Perspectives on Democracy in the Twenty-First Century. Berlin: Springer.

Brennan, J. (2016) Against Democracy. Princeton, NJ: Princeton University Press.

Buchanan, A. (2004) Political liberalism and social epistemology. Philosophy and Public Affairs 32(2): 95-130.

Caplan, B. (2007) The Myth of the Rational Voter: Why Democracies Choose Bad Policies. Princeton, NJ: Princeton University Press.

Christiano, T. (2012) Rational deliberation among experts and citizens. In J. Parkinson and J. Mansbridge (eds.) Deliberative Systems: Deliberative Democracy at the Large Scale. Cambridge: Cambridge University Press.

Collins, H. and Evans, R. (2007) Rethinking Expertise. Chicago, IL: University of Chicago Press.

Dahl, R. (1985) Controlling Nuclear Weapons: Democracy versus Guardianship. Syracuse, NY: SUNY Press.

Dahl, R. (1989) Democracy and Its Critics. New Haven, CT: Yale University Press.

Dewey, J. (1927) The Public and Its Problems. Chicago, IL: The Swallow Press.

Elster, J. (1995) Strategic uses of argument. In: K. Arrow, R. Mnookin, L. Ross, A. Tversky and R. Wilson (eds.) Barriers to Conflict Resolution. New York: Norton.

Elster, J. (2013) Securities against Misrule. Cambridge: Cambridge University Press.

Estlund, D. (1993) Making truth safe for democracy. In: D. Copp, J. Hampton and J. Roemer (eds.) The Idea of Democracy. Cambridge: Cambridge University Press.

Estlund, D. (2008) Democratic Authority: A Philosophical Framework. Princeton, NJ: Princeton University Press.

Foucault, M. (2001) Fearless Speech. Los Angeles, CA: Semiotext(e).

Gesang, B. (2010) Are moral philosophers moral experts? Bioethics 24(4): 153-59. 
Goldman, A. (2001/2011) Experts: Which ones should you trust? In: A. Goldman and D. Whitcomb (eds.) Social Epistemology: Essential Readings. Oxford: Oxford University Press.

Goodin, R. and List, C. (2001) Epistemic democracy: Generalizing the Condorcet Jury Theorem. Journal of Political Philosophy 9(3): 277-306.

Habermas. J (1963/1974) The Scientization of Politics and Public Opinion, in Toward a Rational Society. Boston, MA: Beacon Press.

Habermas, J. (1972/1984) Wahrheitstheorien, in Habermas, J., Vorstudien und Ergänzungen zur Theorie des kommunikativen Handelns. Frankfurt am Main: Suhrkamp.

Hardwig, J. (1985) Epistemic dependence. Journal of Philosophy 82(7): 335-349.

Hardwig, J. (1991) The role of trust in knowledge. Journal of Philosophy 88(12): 693-708.

Hoffman, M. (2012) How to identify moral experts? An application of Goldman's criteria for expert identification to the domain of morality. Analyse $\mathcal{E}$ Kritik: Zeitschrift für Sozialtheorie 34(2): 299-313.

Holst, C. and Molander, A. (2017) Public deliberation and the fact of expertise: Making experts accountable. Social Epistemology 31(3): 235-250.

Jeffrey, A. (2017) Limited epistocracy and political inclusion. Episteme. doi:10.1017/epi.2017.8

Kahneman, D. (2012) Thinking, Fast and Slow. London: Penguin Books.

Kahneman, D. and Tversky, A. (1974) Judgment under uncertainty: Heuristics and biases. Science 185(4157): 1124-1131.

Lamont, M. (2009) How Professors Think: Inside the Curious World of Academic Judgment. Cambridge, MA: Harvard University Press.

Landemore, H. (2012) Democratic Reason: Politics, Collective Intelligence, and the Rule of the Many. Princeton, NJ: Princeton University Press.

Locke, J. (1690/1997) An Essay Concerning Human Understanding. Ed. By R. Woolhouse. London: Penguin Books 
Marti, J.L. (2013) Why (deliberative) democracy has epistemic value and why that is not enough to justify it. Paper presented at the EPISTO Conference, Oslo.

Meade, E.E. and Stasavage, D. (2008) Publicity of debate and the incentive to dissent: Evidence from the US Federal Reserve. The Economic Journal 118: 695-717.

Meehl, P.E. (1954) Clinical versus Statistical Prediction: A Theoretical Analysis and a Review of the Evidence. Minneapolis, MN: University of Minnesota Press.

Mercier, H. (2011) When experts argue: Explaining the best and the worst of reasoning. Argumentation 25: 313-327.

Merton, R.K. (1942/1973) The Sociology of Science: Theoretical and Empirical Investigations. Chicago, IL: University of Chicago Press.

Mill, J.S. (1859/1989) On liberty. In: S. Collini (ed.) On Liberty and Other Writings. Cambridge: Cambridge University Press.

Molander, A. (2016) Discretion in the Welfare State: Social Rights and Professional Judgment. London: Routledge.

Molander, A., Grimen, H. and Eriksen, E.O. (2012) Professional discretion and accountability in the welfare state. Journal of Applied Philosophy 29(3): 214-230.

Moore, A. (2014) Democratic reason, democratic faith, and the problem of expertise. Critical Review 26(1-2): 101-114

Moore, A. (2017) Critical Elitism. Deliberation, Democracy, and thr Problem of Expertise. Cambridge: Cambridge University Press.

Myrdal, G. ([1930]1953) The Political Element in the Development of Economic Theory. London: Routledge

Page, S.E. (2007) The Difference. How the power of Diversity Creates Better Groups, Firms, Schools, and societies. Princeton: Princeton University Press.

Peter, F. (2011) Democratic Legitimacy, New York, NY: Routledge.

Pettit, P. (2004) “Depoliticizing Democray”, Ratio Juris 17( 1): 52-65. 
Quirk, P. J. (2010) 'The trouble with experts. Critical Review, 22:4, 449-465

Reiss, J. (2008) Error in Economics. Towards a More Evidence-Based Methodology. London\&New York: Routledge

Rudner, R. 1953. "The scientist qua scientist makes value judgments." Philosophy of Science 20(1): 1-6.

Schlefer, J. (2012) The Assumptions Economists Make. Cambridge, MA: Harvard University Press.

Schwartzberg, M. (2015) Epistemic democracy and its challenges. The Annual Review of Political Science 18: 187-203.

Singer, P. (1972) Moral experts. Analysis 32(4): 115-117.

Sunstein, C.R. (2006) Infotopia: How Many Minds Produce Knowledge. Oxford: Oxford University Press.

Sunstein, C.R. (2014) Why Nudges? The Politics of Libertarian Paternalism. New Haven, CT: Yale University Press.

Sunstein, C.R. and Hastie, R. (2015) Wiser: Getting beyond Groupthink to Make Groups Smarter. Boston, MA: Harvard Business Review Press.

Swift, A. and White, S. (2008) Political theory, social science, and real politics. In: Leopold, D. and Stears, M. (eds.), Political Theory. Methods and Approaches. Oxford: Oxford University Press.

Tellman, S.M. (2012) The constrained influence of discourses: The case of Norwegian climate policy. Environmental Politics 21(5): 734-752.

Tellman, S.M. (2017) Bounded deliberation in public committees: The case of experts. Critical Policy Studies. 11:3: 311-29.

Tetlock, P. (2005) Expert Political Judgment: How Good Is It? How Can We Know? Princeton, NJ: Princeton University Press. 
Tetlock, P. and Gardner, D. (2016) Superforecasting: The Art and Science of Prediction. New York: Crown.

Thompson, A. (2014) Does diversity trump ability? An example of the misuse of mathematics in social science. Notices of the American Mathematical Society 61: 1024-1030.

Tranøy, K.E. (1976) Norms of inquiry: Methodologies as normative systems. In: G. Ryle (ed.) Contemporary Aspects of Philosophy. London: Oriel Press.

Turner, S. (2003) Liberal Democracy 3.0. London: Sage.

Tversky, A. and Kahneman, D. (1974) Judgment under uncertainty: Heuristics and biases. Science 185: 1124-1131.

Urbinati, N. (2014) Democracy Disfigured: Opinion, Truth, and the People. Cambridge, MA: Harvard University Press.

Vibert, F. (2007) The Rise of the Unelected. Democracy and the New Separation of Powers. Cambridge: Cam,bridge University Press.

Viehoff, D. (2016) Authority and expertise. Journal of Political Philosophy 24(4): 406-426.

Walton, D. (1997) Appeal to Expert Opinion: Arguments from Authority. University Park, PA: Pennsylvania State University Press.

Wildavsky, A. (1979) Speaking Truth to Power: The Art and Craft of Policy Analysis. London: Transaction.

Zenker, F. (2011) Experts and bias: When is the interest-based objection to expert argumentation sound? Argumentation 25: 355-370. 